\title{
STRATEGIES FOR ENHANCING STUDENTS' PRACTICAL SKILLS ACQUISITION IN ELECTRICAL INSTALLATION AND MAINTENANCE WORK IN TECHNICAL COLLEGES IN RIVERS STATE, NIGERIA
}

\author{
Nwauzi K. K. ${ }^{1}$, Azubuike Ovundah ${ }^{2}$, Kingsley C.Anah ${ }^{3}$ \\ ${ }^{1}$ Department of electrical/Electronic Engineering, Elechi Amadi Polytechnic, Rumuola Portharcourt \\ ${ }^{2}$ Department of Industrial Technical Education, Ignatius Ajuru University of Education Rumuolumeni, Portharcourt \\ ${ }^{3}$ Department of Industrial Technical Education Ignatius Ajuru University of Education Rumuolumeni, Portharcourt
}

Corresponding Email: kkirian@yahoo.com(Tel: +2348037921352)

DOI: $10.31364 /$ SCIRJ/v9.i03.2021.P0321845

http://dx.doi.org/10.31364/SCIRJ/v9.i03.2021.P0321845

\begin{abstract}
The study was carried out to determine strategies for enhancing student's practical skills in Electrical Installation and Maintenance Work in Technical Colleges in River's State. A descriptive Survey was used for the study. The population for the study was 48 Electrical teachers and 12 administrators in technical colleges in River's state. The study was carried out in River's state. A structured questionnaire was used as instruments for data collection. two research questions and tow null hypotheses guided the study. Cronbach Alpha method was used for the reliability of the instrument which yielded a coefficient of .75 validity of the instrument. Mean and standard deviation were used to analyze the data for answering research questions while $\mathrm{t}$ - test was used to test the hypotheses of no significant difference at .05 level of significance. The study found out that: eight (8) information and communication technology skills are required for enhancing students practical in Electrical Installation and Maintenance Work, twenty (5) skills are needed for domestic installation work in teaching and learning of electrical installation and maintenance Work in technical colleges and twenty five (5) industrial installation skills are needed in teaching and learning of electrical installation work and maintenance in technical colleges in River's state. It recommended Integration of Information Communication Technology in to Technical College Curriculum in River's state, Siwes should employ and train more manpower for adequate Monitoring /Supervision of Electrical installation and maintenance work students and suggestions for further research studies were also made in the study.
\end{abstract}

Keywords: Practical Skills Acquisition, Strategies, Electrical Installation and Maintenance Work, and Technical Colleges

\section{Introduction}

Skills are procedural principles for manipulating scientific tools and equipment by students that could be gained through experience and training on skill acquisition and development. According to Okorie (2010), skills are the work people carry out which can be classified into the following fundamental skills: communication skills, computation skills, manual dexterity or motor skill as well as human relation skills. Practical Skills are skills for a leverage society. They are skills performed through the psychomotor domains of human being using tools and equipment or technology requiring guidance. Skill is the ability to carry out a task associated with practical roles such as Electrical installation and maintenance work, radio respire, metal work, mechanical technology, engineering and sciences among others (Cosmas 2010).

www.scirj.org

(C) 2021, Scientific Research Journal

http://dx.doi.org/10.31364/SCIRJ/v9.i03.2021.P0321845

This publication is licensed under Creative Commons Attribution CC BY. 
Practical skills are the analysis of complex figures or the specific tools. A skilled person is an individual that has undergone an extensive training in his job and there by mastered the activities that lead to successful performance in the concerned profession, trade or job. As learned ability to do something well, correctly or right, skill involves mastering due to training, exposure or practice; though there could be some personality traits enhancing the rapidity of the acquisition and perfection of technical skills in electrical installation and maintenance work (James 2015).

Electrical installation and maintenance work skills are manual agility through recurring performance of an operation. Moreover skill is proficiency, trained ability, Agility of dexterity. Trainees can gain skills through know-how and training on skill acquisition and development (Abdullahi2016). Skill acquisition is the method by which individuals are anticipated to be taught and continuous carry out a particular task till the trainees becomes competent in the operation and can perform them when the need arises. Skills are acquired when technical instructions are harmonized with performance activities. For skills to be acquired there must be opportunities for participation and practice of such skills under real life situation. According to Donli (2004). skill acquisition is the manifestation of idea and knowledge through training which is geared towards instilling in trainees, the spirit of self- reliance needed for meaningful development in the society. He strained that if students are given the opportunity to acquire important skills needed for selfsustenance in the economy, it will uphold their personality in any work situation. He further maintains that skill acquisition increases competition and teamwork with others. However Electrical installation works and maintenance, is one of the technical trades that is been offered in technical colleges and approved craft centers situated in Rivers State. As a course of study, electrical installation and maintenance work programme at this segment of general educational system is designed to produce skilled manpower for domestic installation, repair of electrical appliances and to be employed in electrical industries. Electrical installation works and maintenance as a course of study comprises of different components or operations which require skills to manage them (NABTEB.2013).

Curriculum of Electrical Installation and Maintenance works Training covers a period of three years. The requisite of this training is to equip electrical installation and maintenance works students with the skills to use diversity of tools and equipment, resulting in the following behavioral objectives: Demonstrate various experiments involving resistors, capacitors and inductors ,Series/parallel connection, Undertake both domestic and industrial installation; Install electrical machines; arrange and join electrical cables, Install/connect batteries for charging systems, use tools to dismantle, recoil and re-couple an electrical machine and undertake tests on installations and machines using appropriate tools (NBTE, 2003). These areas of operation require that students of electrical installation works and maintenance to possess the required skills to carry out these tasks. Electrical installation and maintenance works is an aspect of vocational technical education. Technical Vocational education and training is a segment of Nigerian educational system that prepares students for jobs involving applied science and modem technology. Technical education courses are: Electrical/Electronics, Automobile, Building and Mechanical Technology among others.

Vocational and technical education is an education for practical skills. It is any form of training which the expected end is to produce skilled personnel's for the purpose of employment, being self-reliant, and contribute meaningfully to national development. Vocational and technical education is that segment of general education which leads to acquisition of practical skills for operation of equipment, appliances and other industrial machines. Uwaifor (2009), define vocational technical education as any form of education whose purpose is to prepare person(s) for employment in an occupation or group of occupations. Sukanta (2012) stated that as human

www.scirj.org

(C) 2021, Scientific Research Journal

http://dx.doi.org/10.31364/SCIRJ/v9.i03.2021.P0321845

This publication is licensed under Creative Commons Attribution CC BY. 
being, one of the major features of man is the ability to acquire knowledge, and what makes this knowledge to excel is also the man's ability to impact this knowledge to others.

However, impacting the necessary skills that is needed for gainful employment and self-reliant is important. Practical Skill acquisition remains the major goal of vocational technical education and this helps to satisfy the personal work needs of both the individual and the society. The level of unemployment in the state is analytical of the reputation and quantity of manpower a vailable. In order to reduce the unemployment of electrical installation and maintenance work graduates and enable them to contribute meaningfully to the development of the societies, electrical installation and maintenance works skills need to be taught by technical teachers. Modern electrical installation and maintenance works tools and equipment for teaching relevant skills in electrical installation and maintenance works must be readily available, also good strategies must be used to enhance students practical skills in electrical installation and maintenance works and certain strategies are to be applied to evaluate students' performance both within and outside school. Without enhancing students practical in electrical installation and maintenance work skills, graduates of electrical installation and maintenance works may not contribute effectively to societal development.

Hence, it is very important to determine strategies for enhancing students' practical skills acquisition in electrical installation and maintenance works in River state. In order to enhance students practical skills acquisition in technical college skills such as electrical installation and maintenance works at technical college level, opportunities must be provided for students to perform that skills they are taught in a setting that is related to the job skills learnt. Once these opportunities are properly provided, it will enhance students' practical skills acquisition. SIWES, which is an acronym for student industrial work experience scheme is one of the skill enhancement programme that can lead to acquisition of employable skills.

Students Industrial Work Experience Scheme (SIWES) is a programme that is designed to equip students with work skills, methods and processes of an industry. It was established in Nigeria in the year 1973 by the industrial training fund (ITF). The scheme was designed to provide industrial and skill enhancement trainings to students that need skills before graduation or completion of their training in the school system. The objectives of SIWES as stated by the industrial Training Fund (ITF) are to; 1) Provide an avenue for students in higher institutions of learning to acquire industrial skills and experience in their course of study. 2) Prepare student for the industrial work situation they will meet after graduation. 3) Expose students to work methods and techniques in handling equipment and machinery that may not be available in their institutions. 4) Make the transition from school to the world of work easier and enhance student's contacts for job placement. 5) Provide students with an opportunity to apply the knowledge in real work situation to their training thereby bridging the gap between theory and practice. 6) Enlist and strengthen employer's involvement in the entire education process and prepare student for employment in industry and commerce (ITF 2013). According to Inyiagu (2012), SIWES is an effort to bridge the gap between theory and practice of engineering, technology, science agriculture, medicine and other industrial related professional educational programme in Nigerian tertiary institutions. Nsu in Ojokuku et al. (2015) opined that the scheme is a planned, supervised training and intervention programme based on stated and specific learning and career objectives, leading to the development of occupational competencies of electrical installation and maintenance work. For this reason it is anticipated that SIWES by its nature will have significant impact on electrical installation and maintenance work student's skills that will enable them perform both pedagogic and electrical practical tasks perfectly. Conversely there is need for enforcement/monitoring of industrial training attachment of students of electrical installation and maintenance work in technical college in River state. However, inculcation of practical skills has being redesigned all over the world to fit into the digital age for competence purpose, as such Information and Communication Technology (ICT) is a dominant tool for enhancing students practical skills in electrical installation and maintenance works in technical college.

www.scirj.org

(C) 2021, Scientific Research Journal

http://dx.doi.org/10.31364/SCIRJ/v9.i03.2021.P0321845

This publication is licensed under Creative Commons Attribution CC BY. 
Information and Communication Technology (ICT) is an electronic device for managing and processing information with the use of soft and hard wares to convert, store, manipulate, protect, transmit, manage, control and retrieve information for the enhancement and productivity of personal and organizational activities (Osakwe 2012). ICT equips the teachers in instructional process, which is one of the most important and generally discussed topics in modern educational system. There is no doubt that utilization of information and communication technology in electrical installation and maintenance work will not just enhance students' practical skills acquisitions but also endow the teachers and instructors ability to transmit employable skills for national development (Peter, Leslie \& Nancy2016).Therefore, information and communication technology (ICT) in electrical installation and maintenance work will develop more interest on the trade as it will aid easy understanding and acquisition of practical skills for technological advancement and national development.

Due to the dynamic nature of our society, students technical skills acquisition in electrical installation and maintenance work needed to be enhance with ICT skills to enable the students compete with their counterparts at the industries or job market. It is of this note that the research wishes to study the strategies for enhancing Students' practical skill acquisition in Electrical Installation and Maintenance works in technical colleges in Rivers state

\section{Statement of the Problem;}

The training programe of electrical installation and maintenance works offered in technical colleges is aimed at equipping the students with prerequisite skills that drive them to contribute meaningfully to their society, gain employment in the industries, be self-reliant and job creators towards reduction of poverty and unemployment in the state and nation at large. However, Electrical installation and maintenance works graduates roam the street unemployed because they cannot be employed in the industries or establish their own businesses

What then could be responsible? Could it be that they lack the necessary practical skills required of them after graduation or could it be that appropriate supervisory strategies which will help enhance students practical skills are not effectively used or applied by supervisor of students industrial work experience scheme during industrial work attachment? The problem of this study therefore is to explore the strategies for enhancing Students' practical skills in Electrical Installation and Maintenance work in technical colleges in Rivers state.

\section{Objectives of the study}

The objective of this studyis to determine the strategies for enhancing Students' practical skill acquisition in Electrical Installation and Maintenance works in technical colleges in Rivers state. Specifically the study sought to determine how:

1. Supervisory strategies of Students industrial training attachment cold enhance students practical skills in electrical installation and maintenance works

2. Information and communication technology skills cold enhance Students' practical skills in Electrical Installation and Maintenance works

\section{Research question}

The following research questions guided the study:

1. What are the information and communication technology skills that cold enhance students' practical skills acquisitions in electrical installation and maintenance work?

wWw.scirj.org

(C) 2021, Scientific Research Journal

http://dx.doi.org/10.31364/SCIRJ/v9.i03.2021.P0321845

This publication is licensed under Creative Commons Attribution CC BY. 
2. What are the supervisory strategies of Students' industrial training attachment that cold enhance students' practical skills acquisitions in electrical installation and maintenance work?

\section{Hypotheses}

The following null hypotheses were tested at .05 level of significance to guide the study

$\mathbf{H O}_{2}$ There is no significant difference between the mean responses of electrical teachers and administrators on information and communication technology skills that cold enhance students' practical skills acquisition in electrical installation and maintenance work

$\mathbf{H O}_{2}$ : There is no significant difference between the mean responses of electrical teachers and administrators on Supervisory strategies of Students industrial training attachment that cold enhance students' practical skills acquisition in electrical installation and maintenance work

\section{Methodology}

Descriptive survey research design was employed in carrying out this study. The research was carried out in four technical colleges in Rivers state. The population of the study comprised 60 respondents which comprised 48 electrical teachers and 12 administrators. A structured questionnaire title, strategies for enhancing students' practical skills in electrical installation and maintenance works (SESPSEIMW), was used for data collection. 20 item questionnaire was a structured type. The structure is based on 5- point response options and values of Strongly Agree (SA) 5 points, Agree (A) 4 points, undecided (U) 3 points, Disagree (D) 2 points and Strongly Disagree (SD) 1 point. Data collected was subjected to analysis using means and standard deviation as well as t-test. To determine the acceptance and rejection level of each items in relation to the research questions, a decision rule based on the real limit number was used and decision were taking that mean responses up to 3.50 and above will be accepted while mean responses 3.49 and blow will be rejected. Standard deviation value close or wide apart will be used to determine homogeneity in perception of the respondents. the decision for null hypotheses are as follows: if the calculated value of the (t-cal) is less than the critical value of ( $\mathrm{t}$-crit), accept the null hypothesis but if the calculated value of the ( $\mathrm{t}-\mathrm{cal})$ is greater than or equal to the critical value of (t-crit) at 0.05 level of significance, then reject the null hypothesis

\section{RESULT}

Research Question 1: What are the information and communication technology skills that cold enhance students' practical skill acquisition in electrical installation and maintenance work?

Table 4.1 Mean and Standard Deviation of Responses of information and communication technology skills that enhances students' practical skill acquisition in electrical installation and maintenance work

www.scirj.org

(C) 2021, Scientific Research Journal

http://dx.doi.org/10.31364/SCIRJ/v9.i03.2021.P0321845

This publication is licensed under Creative Commons Attribution CC BY. 


\section{$\begin{array}{llll}\text { S/NO } & \text { INFORMATION } & \text { AND } & \text { TEACHERS }\end{array}$ COMMUNICATION}

\section{TECHNOLOGY}

1.

\begin{tabular}{|c|c|c|c|c|c|c|}
\hline & $\mathbf{X}$ & SD & REMARK & $\mathbf{X}$ & SD & REMARK \\
\hline $\begin{array}{l}\text { Information and communication } \\
\text { technology cold enhance students } \\
\text { skills in troubleshooting }\end{array}$ & 4.00 & .000 & High Extent & 4.43 & .609 & High Extent \\
\hline $\begin{array}{l}\text { Utilization of information and } \\
\text { communication technology cold } \\
\text { enhance students skills in electrical } \\
\text { drawing }\end{array}$ & 3.44 & .693 & Moderate Extent & 4.13 & .649 & High Ext \\
\hline
\end{tabular}

3. Information and communication technology cold enhance students skills in transformer installation

skills in transformer installation

4. Information and communication technology cold enhances students

skills in cable jointing

5 Adequate utilization of information High Extent

High Extent

and communication technology cold enhance students skills in cable neat ting

6. Information and communication technology cold enhance students practical skills in installation of gardening light

7. Utilization of information and communication technology cold enhance students skills in keeping

a record of

accidents for

management use

8. Information and communication 
skills transformer testing

9. Information and communication technology cold enhance skills in Describe with sketches and state where each of the following types of drills are best suited

10. Appropriate utilization of information and communication technology cold enhance students

skills in reading of electrical drawing

\section{Grand mean}

High Extent

4.10
.581

High Extent

The data in table 1 revealed that teachers had a mean range of $3.42-3.44$ and standard deviation of .841 - .693. While the administrators had a mean range of $3.79-4.55$ and standard deviation of $.581-1.238$. The grand mean are 3.959 and 4.168 for teachers and administrators respectively, which are above the real limit of 3.50. The respondents agreed with item 1, 3, 4. 5, 7, 8, 9, and 10 which indicate that information and communication technology is one of the strategies that cold enhance students' practical skills acquisitions in electrical installation and maintenance work in technical colleges in River's state. The closeness of the standard deviation indicated that the respondents were homogeneous or closely to their opinion.

Research Question 2 To what extent does supervisory strategies of Students industrial training attachment enhancing student's practical skills in electrical installation work and maintenance in River state.

Tables 2Mean and Standard Deviation of Responses of Supervisory Strategies of Students Industrial Training Attachment for Practical Skills in Electrical Installation and Maintenance Work

\section{STUDENTS INDUSTRIAL \\ WORK STRATEGIES}

\section{TEACHERS}

X SD REMARK

$3.49 \quad .714$
High Extent

\section{ADMINISTRATORS}

$\mathbf{X}$

SD

REMARK

1 Enforcement of industrial training attachment of students enhances students skills in Identify the various types of drilling

www.scirj.org 
Machines

2 Monitoring of industrial training attachment of students enhances students practical $3.65 \quad .556$

High Extent

$4.06 \quad .756$

High Extent

skills in lighting arrestor

installation

Appropriate supervision of industrial training attachment

of students enhances students

$3.68 \quad .520$

High Extent

4.04

.614

High Extent

practical skills in conduit pipe

bending

4 Monitoring of industrial

training attachment of students

enhances student practical

$3.87 \quad .404$

High Extent

3.93

.910

High Extent

skills in domestic building earthling process.

5 Appropriate supervision of

High Extent

High Extent industrial training attachment of students enhances students

skills in miniature transformer coil winding

6 Enforcement of industrial training attachment of students enhances students skills in $\begin{array}{lllll}3.70 & 667 & \text { High Extent } & 3.97 & .717\end{array}$ cable selection

7 Monitoring of industrial training attachment of students enhances students skills in $3.71 \quad .558$ High Extent 3.94 .903

High Extent identification of conductors in sizes 
8 Appropriate supervision industrial training attachment of students enhances students
3.76
.604
High Extent
4.03
.953
High Extent

practical skills in armored

cable laying

9 Monitoring of industrial training attachment of students enhances students skills in

$\begin{array}{lllll}3.73 & 571 \quad \text { High Extent } & 4.16 & .665 & \text { High Extent }\end{array}$
cable rating

10 Enforcement of industrial attachment of students enhances students skills in
3.70
.607
High Extent
3.88
1.023
High Extent

Battery charging

Grand mean

3.696 .3440

High Extent

3.993

$\mathbf{5 4 1 7}$ High Extent

The data in table 4.5 revealed that teachers had a mean range of $3.49-.3 .87$ and standard deviation of .404 - .714 while the administrators had a mean range of 3.88 - 4.06 and standard deviation of .614.-.953.The grand mean are 3.696 and 3.993 for teachers and administrators respectively, which are above the real limit of 3.50. The respondents agreed with all the items in table 4.5. This indicates that supervisory strategies of Students industrial training attachment enhances students' practical skills in electrical installation and maintenance work technical colleges in River state. The closeness of the standard deviation indicated that the respondents were homogeneous or closely to their opinion.

HO1: There is no significant difference between the mean responses of electrical teachers and administrators on utilization of information and communication technology for enhancing student's practical skills in electrical installation work and maintenance.

The test of this hypothesis was made in respect of appropriate data gathered and presented in Table 4.6

Table 3: t-test on information and communication technology for practical skills in electrical installation work and maintenance.

\begin{tabular}{llllllll}
\hline GROUPS & $\mathbf{N}$ & MEAN & SD & DF & t-cal & t-cri & Decision \\
Teachers & $\mathbf{5 5}$ & 2.091 & 0.4228 & & & & \\
& & & & $\mathbf{9 6}$ & $\mathbf{- 4 . 9 4 6}$ & $\mathbf{1 . 9 6}$ & Accepted \\
Administrators & $\mathbf{5 5}$ & 2.081 & 0.4419 & & & & \\
\hline
\end{tabular}

www.scirj.org

(C) 2021, Scientific Research Journal

http://dx.doi.org/10.31364/SCIRJ/v9.i03.2021.P0321845

This publication is licensed under Creative Commons Attribution CC BY. 
Table 3 revealed that the $\mathrm{t}-\mathrm{cal}(-4.946)$ is less than the $\mathrm{t}$-crit (1.96). This indicates that the null hypothesis is accepted. Therefore, there is no significant difference between the mean responses of electrical teachers, and administrators on of information and communication technology for enhancing student's practical skills in electrical installation work and maintenance.

H02: There is no significant difference between the mean responses of electrical teachers and students on supervisory strategies of Students industrial training for enhancing students' practical skills in electrical installation work and maintenance in River state.

The test of this hypothesis was made in respect of appropriate data gathered and presented in Table 4.10

Table 4 t-test on Supervisory Strategies of Students Industrial Training for Practical Skills in Electrical Installation andMaintenance Work

\begin{tabular}{llllllll}
\hline GROUPS & $\mathbf{N}$ & MEAN & SD & DF & t-cal & t-cri & Decision \\
Teachers & $\mathbf{4 5}$ & 3.696 & .3440 & & & & Accepted \\
& & & & $\mathbf{9 6}$ & $\mathbf{- 3 . 8 6 5}$ & $\mathbf{1 . 9 6}$ & \\
Administrators & $\mathbf{5 5}$ & 3.993 & .5417 & & & \\
\hline
\end{tabular}

Table 4 revealed that the t-cal (-3865) is less than the t-crit (1.96). This indicates that the null hypothesis is accepted. Therefore, there is no significant difference between the mean responses of electrical teachers and students on Students' industrial training strategy for enhancing students' practical skills in electrical installation work and maintenance in River state.

\section{DISCUSSION OF FINDINGS}

The findings of the research shows that utilization of information and communication technology in electrical installation and maintenance work will not just enhance students' practical skills acquisitions but also endow the teachers and instructors ability to transmit employable skills for national development. The finding of the study is in agreement with Ifejiofor et al (2015) who affirmed that Ict has the capacity to provide higher interactive potential for users to develop their individual, intellectual and creative-ability. In line with the above ICT, if fully integrated in electrical installation and maintenance work curriculum will enhances students' practical skills in technical colleges.

The findings of the research also reveals that SIWES bridges the gap between theory and practice acquisitions of engineering, technology, science agriculture, medicine and other industrial related professional educational programme in Nigerian tertiary institutions. The finding of the study is in agreement with Nsu (2012), who opined that the scheme is a planned, supervised training and intervention programme based on stated and specific learning and career objectives, leading to the development of occupational competencies of the participants. In line with the above Abraham-Ibe (2015) stated that students' work experience scheme is an educational programme where students participate in work activities while still attending school. This gives students the opportunity to be directly involved and be part of the actual work situation outside the classrooms.

\section{Conclusion}

www.scirj.org

(C) 2021, Scientific Research Journal

http://dx.doi.org/10.31364/SCIRJ/v9.i03.2021.P0321845

This publication is licensed under Creative Commons Attribution CC BY. 
In terms of overall findings, indicate that information and communication technology is one of the strategies that cold enhance students' practical skills acquisitions in electrical installation and maintenance work. Moreover supervisory strategies of Students industrial training attachment improves students' practical skills in electrical installation and maintenance work in technical colleges in River state

\section{Recommendations}

1. SIWES should employed and train more manpower for adequateMonitoring /Supervision of Electrical installation and maintenance work students.

2. Integration of Information Communication Technology in to Technical College Curriculum in River's state.

\section{References}

Abdullahi, (2016),Development And Validation Of Electrical Installation And Maintenance

Work Intelligence TutorFor Technical Colleges In Nigeria phd thesis university of Nigeria Nsuka.

Ifejiofor, Adaobi Patricia, Nwankwo, \& Cosmas Anayochukwu, (2015), The Undercurrents of ICT Skill Acquisition in Nigeria: Problems and Prospects International Journal of Research in Business Studies and Management Volume 2, Issue 8, August 2015, PP 1-7 ISSN 2394-5923 (Print)

\& ISSN 2394-5931.

Industrial Training Fund (ITF) 2013. Information and Guidelines for Students, Industrial Work Experience Scheme Developing the Nations Human resources.

Inyiagu, E.E. (2012). Introduction to students industrial work experience scheme: A practical guide for successful industrial training . Enugu: New Generation Books

James E. O (2016) Impact of Siwes on Electrical Technology Education Students' Skill Acquisition, Journal of Natural Sciences Research www.iiste.org ISSN 22243186 (Paper) ISSN 2225-0921 (Online) 5(22),2224-3186

National Board for Technical Education (2003). Building technology curriculum. Kaduna: NBTE.

National Board for Technical Education Board (2013). Syllabus for electrical installation trade. Benin:

NABTEB.

www.scirj.org

(C) 2021, Scientific Research Journal

http://dx.doi.org/10.31364/SCIRJ/v9.i03.2021.P0321845

This publication is licensed under Creative Commons Attribution CC BY. 
.Nsu , J. (2012). Evaluation of student industrial work experience scheme (SIWES) in library school: The federal polytechnic Nekede experience. Retrieved from Digital Commons@University of Nebraska-Linc http://digitalcommons.unl.edu/libphilprac/728/.

Okorie, E. U.(2010), Secondary schools chemistry curriculum reforms in the 21st century: implication for educational system. Curriculum and Media Technology Research - J. CUDIMAC, 2 (1), Sept. 2010, 108-119.

Osakwe, R. N. (2012). Problems and Prospects of using information and communication technology for record keeping in tertiary institutions in Nigeria. A Journal of the Faculty of Education Delta State University, Abraka.

Ojokuku B.Y, Emeahara EN, Aboyade M.A, Chris-Israel H.O (2015). Influence of students' Industrial work experience scheme on professional development of library and information science students in South- West, Nigeria". Library Philosophy and Practice (e-journal). 1330 journal).1330.http://digitalcommons.unl.edu/libphilprac/1330.

Peter P. Leslie P. W., \& Nancy O (2016). Making IT Count Strategy, Delivery, Infrastructure Butterworth-Heinemann An imprint of Elsevier Science Linacre

Uwaifo, V.O. (2009). Industrializing the Nigerian Society through Creative Skill Acquisition. Retrieved on 24/4/2019 from googlesearchwebsite

www.scirj.org

(C) 2021, Scientific Research Journal

http://dx.doi.org/10.31364/SCIRJ/v9.i03.2021.P0321845

This publication is licensed under Creative Commons Attribution CC BY. 